\title{
Efek Penyakit Kronis terhadap Gangguan Mental Emosional
}

\section{Effects of Chronic Illness to the Mental Emotional Disorders}

\author{
Giri Widakdo* Besral ${ }^{* *}$
}

\begin{abstract}
*Fakultas Kedokteran dan Kesehatan Universitas Muhammadiyah Jakarta, **Departemen Biostatistika dan Ilmu Kependudukan Fakultas Kesehatan Masyarakat Universitas Indonesia
\end{abstract}

\begin{abstract}
Abstrak
Hasil Riset Kesehatan Dasar tahun 2007 menunjukkan 11,6\% penduduk Indonesia berumur 15 tahun ke atas mengalami gangguan mental emosional. Penelitian ini bertujuan untuk mengetahui efek penyakit kronis terhadap gangguan mental emosional. Desain penelitian ini adalah potong lintang mengggunakan data Riskesdas tahun 2007. Sebanyak 660.452 responden berusia di atas 15 tahun yang tidak mengalami gangguan jiwa dijadikan sampel. Gangguan mental emosional dinyatakan ada jika responden mempunyai paling tidak enam dari 20 gangguan. Penyakit kronis seperti tuberculosis (TB) paru, hepatitis, jantung, diabetes, kanker, dan stroke diukur melalui wawancara yang didasarkan pada diagnosis petugas kesehatan. Hasil penelitian menunjukkan bahwa dari sepuluh penderita penyakit kronis, dua sampai lima penderita akan mengalami gangguan mental emosional. Analisis regresi logistik multivariat memperlihatkan bahwa risiko gangguan mental emosional semakin tinggi bersamaan dengan semakin banyak jumlah penyakit kronis yang diderita oleh responden. Responden yang menderita satu penyakit kronis berisiko 2,6 kali lebih besar untuk mengalami gangguan mental emosional, yang menderita dua penyakit kronis berisiko 4,6 kali, yang menderita tiga penyakit kronis atau lebih berisiko 11 kali. Kementerian Kesehatan disarankan untuk mengembangkan standar pelayanan penyakit kronis terkait dengan pengurangan dampak pada gangguan mental emosional dan dibentuknya tim bimbingan teknis pelayanan penyakit kronis.
\end{abstract}

Kata kunci: Emosional, gangguan mental, penyakit kronis,

\section{Abstract}

Basic Health Research (Riskesdas) year 2007 showed that 11.6 percent of Indonesia's population aged 15 years and above suffering from mental emotional disorder. This study aimed to examine the effects of chronic illness to the mental emotional disorders. A cross-sectional study was performed that used Riskesdas 2007 data. A total of 660,452 respondents aged 15 years and over who are mentally health become sample of this study. Mental emotional disorders exist if they have at least six of the 20 disorder. Chronic diseases such as pulmonary tuberculosis, hepatitis, heart disease, diabetes, cancer, and stroke were measured based on diagnosis by health profesional. The results showed that out of ten respondents with chronic illness, aproximately two to five will suffering from mental emotional disorder. Multivariat logistic regression analysis shows that the risk of developing mental emotional disorders higher as more number of chronic illnesses suffered by the respondent. Respondents suffering from one chronic disease were 2.6 times greater risk for emotional mental disorder, suffering from two chronic disease have risk 4.6 times, which had three or more chronic disease risk have risk 11 times. It is suggested that the Ministry of Health to develop a standard of care of chronic diseases associated with reducing impact on the mental emotional disorders and establishment of teams for technical guidance chronic disease care.

Keywords: Emotional, mental disorder, chronic disease,

\section{Pendahuluan}

Gangguan kesehatan jiwa merupakan sindrom, pola perilaku atau kondisi psikologi seseorang yang secara klinik cukup bermakna dan secara khas berkaitan dengan suatu gejala (distress, impairment, atau disability) di dalam satu atau lebih fungsinya dalam segi perilaku psikologis atau biologi atau gangguan jiwa dalam hubungan antara orang itu dengan masyarakat. ${ }^{1}$ Setiap orang berpotensi mengalami gangguan kesehatan jiwa yang salah satu faktor risikonya adalah penyakit fisik yang bersifat kronis sepanjang berinteraksi dengan lingkungan dan terus terlibat dalam kemajuan zaman. ${ }^{2}$ Pasien

Alamat Korespondensi: Besral, Departemen Biostatistika dan Ilmu Kependudukan FKM Universitas Indonesia, Gd. A Lt. 2 Kampus Baru UI Depok 16424, Hp.085880984413, e-mail: besral@yahoo.com 
dengan penyakit fisik yang serius mempunyai gangguan psikiatri sedikitnya dua kali lipat dibanding populasi umum. Semua pasien rawat inap dan rawat jalan di rumah sakit sebanyak $20-40 \%$ mengalami gangguan psikiatri. ${ }^{3}$ Penyakit jantung, stroke, kanker dan penyakit kronis lainnya sering dianggap menjadi masalah kesehatan masyarakat hanya untuk negara-negara berpenghasilan tinggi padahal sebetulnya tidak. Pada kenyataannya, hanya $20 \%$ dari kematian penyakit kronis terjadi di negara berpenghasilan tinggi, sementara $80 \%$ terjadi di negara-negara berpenghasilan rendah dan menengah yang menjadi sebagian besar keberadaan penduduk dunia. $^{4}$

Di Asia, dalam 12 tahun terakhir terjadi kenaikan prevalensi gangguan mental (mental disorder). Di Jepang, prevalensi gangguan mental berat sebesar $1,5 \%$, gangguan mental sedang $4,1 \%$, dan gangguan mental ringan 3,2\%.5 Di Indonesia, prevalensi ganguan mental emosional dari data 30 provinsi di Indonesia pada penduduk usia 15 tahun keatas sebesar 11,6\%, pada lakilaki $9,0 \%$ dan pada perempuan $14,0 \% .6$

Berbagai studi memperlihatkan bahwa ada kaitan yang erat antara penyakit kronis dengan gangguan mental emosional. Sekitar 25\% perempuan mengalami gangguan afektif setelah dilakukan pembedahan payudara. Selain itu, sekitar 13 - 19\% dari pasien dengan myocard infark (MI) menderita gangguan depresi major. ${ }^{7}$ Sifat ketidakpercayaan, kemarahan, dan agresif adalah faktor risiko tidak hanya untuk penyakit jantung jantung koroner (PJK) tetapi juga faktor risiko hampir semua penyakit fisik. ${ }^{7}$ Ada hubungan yang kuat antara hepatitis kronis dengan depresi. ${ }^{8}$ Akibat lain dari stroke adalah terjadi penurunan parsial sampai total gerakan dari lengan atau tungkai sebanyak $80 \%$, penurunan dalam berpikir atau mengingat $80-90 \%$, menderita depresi $70 \%$, dan mengalami kesulitan bicara, menelan, atau membedakan kanan dan kiri 30\%. ${ }^{9}$ Penelitian ini bertujuan untuk mengetahui efek dari penyakit kronis terhadap kejadian gangguan mental emosional di Indonesia.

\section{Metode}

Penelitian ini merupakan penelitian analitik dengan rancangan potong lintang atau cross-sectional yang merupakan desain penelitian yang memotret suatu kejadian dan efek pada waktu yang bersamaan. Penelitian ini menggunakan data sekunder hasil Riset Kesehatan Dasar (Riskesdas) tahun 2007. Sampel Riskesdas 2007 berasal dari 440 kabupaten/kota yang tersebar di 33 provinsi di Indonesia. Populasi penelitian ini adalah semua penduduk berusia lebih dari 15 tahun di Indonesia. Sedangkan sampelnya adalah 660.452 responden penduduk berusia 15 tahun ke atas yang menjadi sampel Riskesdas 2007 dengan kriteria tidak sedang mengalami gangguan jiwa, bisa berkomunikasi dan menjawab seluruh pertanyaan pada kuesioner. Pengukuran gangguan mental emosional menggunakan kuesioner RKD07.IND.X pertanyaan nomor F01 sampai F20 yang ditanyakan kondisi satu bulan terakhir kepada semua anggota rumah tangga yang berusia 15 tahun atau lebih. Responden dinyatakan mengalami gangguan mental emosional jika mengalami paling tidak enam dari 20 kondisi gangguan mental emosional dalam kurun waktu sebulan terakhir sesuai dengan instrumen yang telah dikembangkan oleh departemen kesehatan. ${ }^{6}$ Responden dinyatakan menderita penyakit kronis seperti tuberculosis paru, hepatitis, jantung, diabetes mellitus (DM), kanker, dan stroke apabila berdasarkan hasil wawancara responden pernah didiagnosis oleh petugas kesehatan mengalami salah satu atau beberapa penyakit tersebut dalam kurun waktu 12 bulan terakhir sebelum survei. Faktor demografi dan ekonomi ikut di-ukur dan dikontrol sebagai variabel perancu. Status ekonomi telah diukur melalui Survei Sosial Ekonomi Nasional yang dilakukan oleh Badan Pusat Statistik dengan menanyakan pengeluaran rumah tangga untuk makanan dan bukan makanan kemudian dikelompokan menjadi lima kelompok berdasarkan nilai kuintal yang tersedia dalam basis data Riskesdas. ${ }^{6}$

Analisis statistik yang digunakan adalah regresi logistik bivariat dan multivariat. ${ }^{10}$ Pemodelan regresi logistik multivariat dilakukan dengan metode backward seperti yang dianjurkan oleh Kleinbaum yakni dengan memasukan semua variabel karakteristik responden dan variabel penyakit kronis, kemudian variabel karakteristik yang tidak signifikan (nilai $\mathrm{p}<0,05$ ) dikeluarkan dari model satu per satu dimulai dari variabel yang mempunyai nilai-p paling besar. ${ }^{10}$ Model regresi logistik multivariat yang dibuat ada dua model, pertama model untuk mengetahui efek masing-masing penyakit kronis terhadap gangguan mental emosional dan yang kedua model untuk mengetahui efek dari kumulatif jumlah penyakit kronis yang dialami oleh responden terhadap kejadian gangguan mental emosional.

\section{Hasil}

Hasil penelitian menunjukkan sebesar $11,58 \%$ penduduk usia 15 tahun di Indonesia tahun 2007 mengalami gangguan mental emosional. Selain itu, sebesar 3,5\% penduduk Indonesia mengalami paling tidak satu dari enam penyakit kronis berikut yaitu TBC, DM, tumor atau keganasan, stroke, hepatitis atau lever, dan jantung. Penyakit kronis terbanyak yang dialami adalah jantung dan diabetes masingmasing sebesar $1,2 \%$ dan $0,95 \%$. Ada kemungkinan mereka menderita lebih dari satu penyakit kronis, namun persentasenya sangat kecil, sebagian besar $(3,14 \%)$ hanya menderita satu jenis penyakit kronis dan hanya 
Tabel 1. Gangguan Mental Emosional dan Penyakit Kronis

\begin{tabular}{lll}
\hline Gangguan Mental dan Penyakit Kronis & Jumlah & Persentase $(\%)^{*}$ \\
\hline Mengalami gangguan mental emosional & 76.512 & 11,58 \\
Menderita penyakit kronis berikut: & & \\
$\quad$ Jantung & 8.001 & 1,21 \\
Diabetes mellitus & 6.249 & 0,95 \\
Tumor/kanker & 3.904 & 0,59 \\
Stroke & 3.972 & 0,60 \\
TBC & 3.025 & 0,46 \\
Hepatitis & 365 & 0,06 \\
Jumlah penyakit kronis yang diderita: & & \\
Menderita 1 jenis penyakit kronis & 20.743 & 3,14 \\
Menderita 2 jenis penyakit kronis & 1.943 & 0,29 \\
Menderita 3 jenis penyakit kronis & 228 & 0,03 \\
Menderita 4 jenis penyakit kronis & 47 & 0,01 \\
\end{tabular}

Keterangan:

*Persentase dan jumlah dihitung dari total responden yaitu penduduk usia 15 tahun atau lebih; $\mathrm{n}=660.452$

Tabel 2. Karakteristik Responden

\begin{tabular}{|c|c|c|}
\hline Karakteristik & Kategori & Persentase $(\%)$ \\
\hline \multirow[t]{7}{*}{ Usia } & $15-24$ tahun & 23,1 \\
\hline & $25-34$ tahun & 23,0 \\
\hline & $35-44$ tahun & 21,2 \\
\hline & $45-54$ tahun & 15,8 \\
\hline & $55-64$ tahun & 9,0 \\
\hline & $65-74$ tahun & 5,4 \\
\hline & 75 tahun ke atas & 2,6 \\
\hline \multirow[t]{2}{*}{ Jenis kelamin } & Laki-laki & 48,1 \\
\hline & Perempuan & 51,9 \\
\hline \multirow[t]{4}{*}{ Status pernikahan } & Belum menikah & 22,4 \\
\hline & Menikah & 69,4 \\
\hline & Cerai hidup/mati & 1,8 \\
\hline & Cerai mati & 6,5 \\
\hline \multirow[t]{2}{*}{ Konsumsi alkohol } & Tidak & 94,4 \\
\hline & Ya & 5,6 \\
\hline \multirow[t]{10}{*}{ Pekerjaan } & PNS/BUMN/swasta/TNI/Polri/sekolah & 17,2 \\
\hline & Wiraswasta/pedagang/pelayanan jasa & 13,4 \\
\hline & Petani/nelayan/buruh/lainnya & 37,6 \\
\hline & Tidak kerja/ibu rumah tangga & 31,8 \\
\hline & Pendidikan perguruan tinggi & 5,4 \\
\hline & Tamat SLTA & 21,2 \\
\hline & Tamat SLTP & 20,2 \\
\hline & Tamat SD & 27,8 \\
\hline & Tidak tamat SD & 16,6 \\
\hline & Tidak pernah sekolah & 8,8 \\
\hline \multirow[t]{3}{*}{ Kebiasaan merokok } & Tidak pernah merokok & 62,6 \\
\hline & Pernah merokok & 3,8 \\
\hline & Perokok & 33,7 \\
\hline \multirow{2}{*}{$\begin{array}{l}\text { Riwayat keturunan } \\
\text { gangguan mental }\end{array}$} & Tidak ada & 99,4 \\
\hline & Ada & 0,6 \\
\hline
\end{tabular}

*Persentase dihitung dari total responden $=660.452$

$0,3 \%$ menderita dua jenis penyakit kronis serta hanya 0,03 menderita tiga jenis penyakit kronis (Tabel 1).

Sebagian besar responden berusia antara $15-44$ tahun dengan rata-rata umur 38 tahun. Responden perempuan sedikit lebih banyak daripada laki-laki (52 banding $48 \%$ ). Dua pertiga responden sudah menikah. Sebagian besar responden berpendidikan rendah (tamat SD atau tidak sekolah, sebesar 53\%), bekerja sebagai petani/buruh/nelayan/lainnya $(37,56 \%)$ dan sepertiganya tidak bekerja atau ibu rumah tangga $(31,81 \%)$. Sepertiga responden adalah perokok, namun hasil analisis lebih lanjut memperlihatkan proporsi perokok berbeda menurut jenis kelamin ( $71 \%$ pada laki-laki dan $6 \%$ pada perempuan). Hanya sebagian kecil yang mengonsumsi alkohol $(5,6 \%)$ dan sangat sedikit yang mempunyai riwayat keturunan dengan gangguan jiwa (0,6 persen) (Tabel 2).

Kejadian terbesar gangguan mental emosional dialami oleh responden yang menderita hepatitis dan stroke ( $47 \%$ dan $42 \%$ ) kemudian diikuti oleh responden yang menderita penyakit jantung dan TBC (34\%) dan responden yang menderita penyakit diabetes mellitus, tumor atau kanker (24\%). Dapat dinyatakan bahwa dari sepuluh penderita penyakit kronis, dua sampai lima penderita mengalami gangguan mental emosional (berkisar $24-47 \%$ ). Apapun jenis penyakit kronis yang dialami oleh responden (TBC, diabetes mellitus, tumor atau keganasan, stroke, hepatitis atau lever, dan jantung) mempunyai hubungan yang bermakna dengan kejadian gangguan mental emosional (nilai p < 0,001) (Tabel 3).

Setelah dikontrol oleh karakteristik responden seperti umur, jenis kelamin, pendidikan, pekerjaan, status merokok, alkohol, dan riwayat keluarga dengan gangguan jiwa, terlihat bahwa risiko responden yang menderita stroke untuk mengalami gangguan mental emosional sebesar 3,5 kali lebih tinggi, risiko penderita TBC dan penyakit jantung untuk mengalami gangguan mental emosional masing-masing sebesar 2,8 dan 3,0 kali lebih tinggi, sedangkan risiko penderita tumor/kanker, hepatitis, dan diabetes mellitus masing-masing sebesar 2,0, 1,8, dan 1,6 kali lebih tinggi dibandingkan dengan yang tidak menderita penyakit tersebut.

Berdasarkan model akhir analisis regresi logistik multivariat hubungan penyakit kronis dan faktor risiko lainnya dengan kejadian gangguan mental emosional, semakin banyak jumlah penyakit kronis yang diderita oleh responden akan semakin besar risikonya untuk menderita gangguan mental emosional. Responden yang menderita 1 penyakit kronis mempunyai risiko 2,7 kali lebih besar untuk menderita gangguan mental emosional, responden yang menderita 2 penyakit kronis mempunyai risiko 4,7 kali lebih besar, sedangkan responden yang menderita 3 atau lebih penyakit kronis mempunyai risiko 11 kali lebih besar. Hasil ini terlihat setelah dikontrol oleh karakteristik responden seperti umur, jenis kelamin, pendidikan, pekerjaan, status merokok, alkohol, dan riwayat keluarga dengan gangguan jiwa. Selain itu, risiko terjadi gangguan mental emosional lebih tinggi pada mereka yang mempunyai riwayat keluarga dengan gangguan jiwa, jenis kelamin perempuan, perokok dan peminum alkohol, pendidikan rendah, pengangguran, janda/duda yang cerai mati atau cerai hidup, dan kelompok usia tua atau diatas 55 tahun (Tabel 4). 
Tabel 3. Efek Penyakit Kronis terhadap Gangguan Mental Emosional

\begin{tabular}{|c|c|c|c|c|c|c|c|c|}
\hline \multirow{2}{*}{ Jenis Penyakit } & \multirow{2}{*}{ Kategori } & \multicolumn{2}{|c|}{$\begin{array}{c}\text { Gangguan Mental } \\
\text { Emosional }\end{array}$} & \multirow{2}{*}{$\mathbf{O R}_{\text {crude }}$} & \multirow{2}{*}{ IK 95\% } & \multirow{2}{*}{$* \mathbf{O R}_{\text {adjusted }}$} & \multirow{2}{*}{ IK 95\% } & \multirow{2}{*}{ Nilai $p$} \\
\hline & & Tidak (\%) & Ya (\%) & & & & & \\
\hline \multirow[t]{2}{*}{ TBC } & Tidak & 88,5 & 11,5 & 3,9 & $3,7-4,3$ & 3,0 & $2,8-3,3$ & $<0,001$ \\
\hline & Ya & 66,0 & 34,0 & & & & & \\
\hline \multirow[t]{2}{*}{ Jantung } & Tidak & 88,7 & 11,3 & 3,9 & $3,8-4,2$ & 2,8 & $7,7-2,9$ & $<0,001$ \\
\hline & Ya & 66,4 & 33,8 & & & & & \\
\hline \multirow[t]{2}{*}{ Diabetes } & Tidak & 88,5 & 11,5 & 2,5 & $2,3-2,6$ & 1,6 & $1,5-1,7$ & $<0,001$ \\
\hline & $\mathrm{Ya}$ & 75,6 & 24,4 & & & & & \\
\hline \multirow[t]{2}{*}{ Tumor/kanker } & Tidak & 88,5 & 11,5 & 2,5 & $2,3-2,6$ & 2,0 & $1,8-2,2$ & $<0,001$ \\
\hline & Ya & 75,7 & 24,3 & & & & & \\
\hline \multirow[t]{2}{*}{ Stroke } & Tidak & 88,6 & 11,4 & 5,7 & $5,3-6,1$ & 3,5 & $3,3-3,7$ & $<0,001$ \\
\hline & Ya & 57,8 & 42,3 & & & & & \\
\hline \multirow[t]{2}{*}{ Hepatitis } & Tidak & 88,4 & 11,6 & 6,9 & $5,6-8,5$ & 1,8 & $1,4-2,2$ & $<0,001$ \\
\hline & Ya & 52,6 & 47,5 & & & & & \\
\hline
\end{tabular}

Keterangan : $\mathrm{OR}=$ Odds Ratio; $\mathrm{IK}$ = Indeks Kepercayaan; * $\mathrm{OR}_{\text {adjusted }}$ setelah dikontrol oleh umur, jenis kelamin, pendidikan, pekerjaan, pernikahan, merokok, alkohol, dan riwayat keluarga dengan gangguan jiwa

\begin{tabular}{|c|c|c|c|c|}
\hline Variabel Prediktor & Kategori & OR & IK 95\% & Nilai $p$ \\
\hline \multirow[t]{4}{*}{ Penyakit kronis } & Tidak & 1,0 & & \\
\hline & Menderita 1 penyakit & 2,65 & $2,57-2,74$ & $<0,001$ \\
\hline & Menderita 2 penyakit & 4,73 & $4,30-5,20$ & $<0,001$ \\
\hline & Menderita 3 penyakit & 10,90 & $8,45-14,06$ & $<0,001$ \\
\hline \multirow[t]{2}{*}{ Mempunyai riwayat keluarga } & Tidak & 1,0 & & \\
\hline & Ya & 3,77 & $3,51-4,05$ & $<0,001$ \\
\hline \multirow[t]{2}{*}{ Jenis kelamin } & Laki-laki & 1,0 & & \\
\hline & Perempuan & 1,73 & $1,69-1,77$ & $<0,001$ \\
\hline \multirow[t]{2}{*}{ Perokok } & Tidak & 1,0 & & \\
\hline & Ya & 1,30 & $1,27-1,33$ & $<0,001$ \\
\hline \multirow[t]{2}{*}{ Mengonsumsi Alkohol } & Tidak & 1,0 & & \\
\hline & Ya & 1,66 & $1,60-1,71$ & $<0,001$ \\
\hline \multirow[t]{5}{*}{ Pendidikan } & Perguruan tinggi & 1,0 & & \\
\hline & Tamat SLTA/sederajat & 1,20 & $1,16-1,23$ & $<0,001$ \\
\hline & Tamat SLTP/sederajat & 1,45 & $1,42-1,49$ & $<0,001$ \\
\hline & Tamat SD/sederajat & 1,73 & $1,68-1,77$ & $<0,001$ \\
\hline & SD tidak tamat & 1,90 & $1,84-1,96$ & $<0,001$ \\
\hline \multirow[t]{4}{*}{ Pekerjaan } & PNS/Swasta/TNI/Polri & 1,0 & & \\
\hline & Wiraswasta/dagang & 1,09 & $1,06-1,13$ & $<0,001$ \\
\hline & Petani/nelayan/buruh & 1,08 & $1,05-1,11$ & $<0,001$ \\
\hline & Tidak bekerja & 1,43 & $1,39-1,47$ & $<0,001$ \\
\hline \multirow[t]{3}{*}{ Pernikahan } & Belum menikah & 1,0 & & \\
\hline & Menikah & 0,93 & $0,91-0,95$ & $<0,001$ \\
\hline & Janda/duda & 1,20 & $1,16-1,24$ & $<0,001$ \\
\hline \multirow[t]{4}{*}{ Usia } & $15-44$ tahun & 1,0 & & \\
\hline & $45-54$ tahun & 1,13 & $1,10-1,15$ & $<0,001$ \\
\hline & $55-64$ tahun & 1,38 & $1,35-1,42$ & $<0,001$ \\
\hline & $65+$ tahun & 2,16 & $2,10-2,22$ & $<0,001$ \\
\hline
\end{tabular}

\section{Pembahasan}

Dalam penelitian yang melibatkan 660.452 responden ini, diketahui bahwa prevalensi gangguan mental emosional pada penduduk usia 15 tahun ke atas di Indonesia adalah $11,58 \%$. Angka ini sama dengan laporan Riskesdas 2007 yang menyatakan prevalensi gangguan mental emosional sebesar $11,6 \%$ karena menggunakan data yang sama. ${ }^{6}$ Artinya, satu dari sepuluh pen- duduk Indonesia mengalami gangguan mental emosional. Prevalensi gangguan mental emosional di Indonesia tidak jauh berbeda dengan negara-negara lain di dunia. Hasil kajian Baumeister dan Härter terhadap literatur yang memublikasikan prevalensi gangguan mental dari hasil survei di populasi umum dari berbagai negara memperlihatkan bahwa prevalensi gangguan mental bervariasi dari $6-18 \% .{ }^{11}$ Beda dengan Amerika Serikat yang 
menunjukkan prevalensi gangguan mental lebih tinggi. Hasil penelitian Kessler et al memperlihatkan bahwa prevalensi gangguan mental pada penduduk Amerika usia 18 - 54 tahun pada periode tahun 2001 - 2003 sekitar $30,5 \%$ dan angka tersebut tidak mengalami perubahan dalam satu dekade terakhir yakni $29,4 \%$ pada periode tahun 1990 - 1992.12

Angka gangguan mental emosional sangat tinggi pada penderita penyakit kronis, hasil penelitian ini memperlihatkan bahwa angkanya berkisar $24-47 \%$. Penderita hepatitis dan stroke mengalami gangguan mental emosional masing-masing sebesar $47 \%$ dan $42 \%$, kemudian diikuti oleh penderita penyakit jantung dan TBC (34\%) dan penderita penyakit diabetes mellitus, tumor, atau kanker (24\%). Dapat dikatakan bahwa dari sepuluh penderita penyakit kronis, dua sampai lima penderita mengalami gangguan mental emosional. Hasil penelitian ini hampir sama dengan penelitian Serrano-Blanco et al (2010) pada 3.815 pasien umur 18 tahun atau lebih yang berasal dari 77 Layanan Kesehatan Primer di Spanyol yang menemukan bahwa $45 \%$ responden pernah mengalami gangguan mental emosional dan $30 \%$ mengalami gangguan mental emosional dalam satu tahun terakhir. Tingginya kejadian gangguan mental emosional ini sangat berkaitan dengan kondisi penyakit kronis yang dialami oleh responden. ${ }^{13}$

Kondisi ini mengkhawatirkan karena secara fisik maupun sosial responden yang mengalami gangguan mental emosional dapat memperparah gangguan fisik penyakit kronis yang dialaminya. Kondisi ini juga dapat mengganggu hubungan individu dengan lingkungannya yang berpotensi menjadikan individu tersebut mengalami gangguan jiwa. Ganguan jiwa adalah sindrom atau pola tingkah laku psikologis yang secara klinis bermakna dari seseorang dan berhubungan dengan penderita (distress) atau disabilitas atau meningkatnya risiko untuk penderita sakit, disabilitas, kematian atau kehilangan kebebasan. ${ }^{14}$ Gangguan jiwa adalah suatu perubahan pada fungsi jiwa yang menyebabkan adanya gangguan pada fungsi jiwa yaitu menimbulkan penderitaan atau hambatan dalam melaksanakan peran sosial. 15

Selain berpontensi mengalami gangguan jiwa, penderita gangguan mental juga berpotensi untuk melakukan bunuh diri. Di Australia, efek gangguan mental berkontribusi sebesar sepertiga dari total kejadian buruh diri di populasi penduduk Australia. Kejadian itu sedikit lebih rendah pada pria (sebesar $28 \%$ ) dibanding wanita (sebesar 36\%) setelah dikontrol oleh umur, pendidikan, pekerjaan, dan status ekonomi. ${ }^{16}$ Survei Nasional Kesehatan Mental dan Kesejahteraan memperlihatkan bahwa gangguan mental merupakan peringkat ketiga terbesar yang berkontribusi dalam beban penyakit di negara bagian Victoria, setelah penyakit kanker dan penyakit jantung-pembuluh darah. Penelitian itu juga menambahkan bahwa depresi merupakan penyebab terbesar kejadian disabilitas baik pada pria maupun wanita. ${ }^{17}$

Hasil analisis regresi logistik multivariat didapatkan bahwa setelah dikontrol oleh karakteristik responden, risiko penderita penyakit kronis untuk mengalami gangguan mental emosional cukup bervariasi yakni berkisar antara 1,6 sampai 3,5 ( $\left.\mathrm{OR}_{\text {adjusted }}\right)$. Jenis penyakit kronis yang mempunyai risiko paling besar untuk mengalami gangguan mental emosional adalah stroke $\left(\mathrm{OR}_{\text {adjusted }}=\right.$ $3,5)$, kemudian diikuti oleh $\mathrm{TBC}\left(\mathrm{OR}_{\text {adjusted }}=3,0\right)$ dan penyakit jantung $\left(\mathrm{OR}_{\text {adjusted }}=2,8\right)$. Jenis penyakit kronis lainnya mempunyai risiko yang sedikit lebih rendah dibanding stroke, TBC, dan jantung untuk mengalami gangguan mental emosional, yakni penyakit tumor/kanker $\left(\mathrm{OR}_{\text {adjusted }}=2,0\right)$, hepatitis $\left(\mathrm{OR}_{\text {adjusted }}=1,8\right)$, dan diabetes mellitus $\left(\mathrm{OR}_{\text {adjusted }}=1,6\right)$.

Responden yang menderita penyakit jantung berisiko 4,6 kali lebih besar untuk mengalami gangguan mental emosional, responden yang menderita diabetes mellitus mempunyai risiko $2,3 \mathrm{kali}$, dan responden yang menderita tumor/kanker mempunyai risiko 2,1 kali lebih besar untuk mengalami gangguan mental emosional. ${ }^{18}$ Menurut Koenig et al dan Stuart, salah satu faktor risiko terjadinya gangguan mental adalah penyakit fisik yang bersifat kronis. Penyakit ini berlangsung cukup lama, baik dalam patofisiologis maupun proses pengobatan serta pemulihannya sehingga cenderung mengakibatkan kematian sebagai akibat adanya gangguan biologis pada sistem saraf pusat sehingga seringkali mempengaruhi fungsi kognitif seseorang dalam memutuskan mekanisme penyesuaian (adaptation) atau pertahanan dirinya (defence mechanism) terhadap masalah yang dihadapinya. 2,19

Hasil analisis regresi logistik multivariat dengan pemodelan lainnya yakni untuk mengetahui efek dari jumlah penyakit kronis yang diderita didapatkan bahwa setelah dikontrol oleh karakteristik responden, risiko untuk mengalami gangguan mental emosional terlihat semakin besar seiring dengan semakin banyaknya jenis penyakit kronis yang diderita oleh responden. Responden yang menderita hanya satu penyakit kronis mempunyai risiko 2,7 kali lebih besar untuk menderita gangguan mental emosional, responden yang menderita dua penyakit kronis mempunyai risiko 4,7 kali lebih besar untuk menderita gangguan mental emosional, sedangkan responden yang menderita 3 atau lebih penyakit kronis mempunyai risiko 11 kali lebih besar untuk menderita gangguan mental emosional pada kondisi karakteristik responden sama seperti usia, jenis kelamin, pendidikan, pekerjaan, status merokok, alkohol, dan riwayat keluarga dengan gangguan jiwa. Hasil penelitian menunjukkan adanya tren meningkat risiko untuk mengalami gangguan mental emosional pada tingkatan atau jumlah penyakit kronis yang diderita responden. Hasil uji hipotesis menunjukkan 
semakin banyak jumlah penyakit kronis yang diderita semakin besar kemungkinan untuk mengalami gangguan mental emosional.

Peningkatan risiko gangguan mental emosional yang sangat besar pada responden yang menderita 3 penyakit kronis atau lebih mungkin terjadi karena responden merasa integritas fisiknya terancam sebagai akibat gangguan atau disabilitas fisiologis sehingga menyebabkan penurunan fungsi sosial. Oleh karena itu, individu atau responden tersebut cenderung menggunakan penyesuaian/pertahanan diri (mekanisme koping) untuk mengatasi kecemasannya. Akan tetapi, karena mekanisme koping tersebut berlangsung secara tidak disadari dapat menjadi respons maladaptif terhadap stres berupa peningkatan risiko gangguan mental emosional. 19

Faktor risiko lain yang berhubungan signifikan dengan gangguan mental emosional adalah usia responden. Berdasarkan hasil regresi logistik multivariat hubungan umur dengan gangguan mental emosional memperlihatkan adanya tren yang meningkat, semakin tua usia seseorang semakin besar risikonya untuk mengalami gangguan mental emosional. Mereka yang berusia 55 - 64 tahun mempunyai risiko 1,4 kali lebih besar untuk mengalami gangguan mental emosional, sedangkan mereka yang berumur 65 tahun atau lebih mempunyai risiko 2,2 kali lebih besar dibandingkan dengan mereka yang berumur $15-44$ tahun. Risiko gangguan mental emosional atau depresi pada pasien sesudah usia 50 tahun mencapai 3 sampai 5 kali lebih besar dibandingkan pasien dengan usia kurang dari 50 tahun dan hal ini lebih disebabkan oleh faktor biologik dan bukan karena faktor genetik. Hal ini juga mungkin disebabkan perubahan pada sistem saraf (neurotransmitter katekolaminergik) yang mungkin berperan dalam terjadinya depresi pada usia lanjut. ${ }^{2}$ Risiko gangguan mental lebih tinggi pada kelompok jenis kelamin perempuan, kelompok dewasa yang tidak menikah, tidak bekerja, dan mempunyai status sosial ekonomi yang rendah. ${ }^{11}$

Hasil lain yang menarik adalah tren dan hubungan yang signifikan antara pendidikan dengan gangguan mental emosional. Semakin rendah pendidikan responden, semakin tinggi risikonya untuk mengalami gangguan mental emosional. Dibandingkan dengan responden tamat perguruan tinggi, mereka yang tamat SLTA/sederajat mempunyai risiko 1,2 kali lebih besar untuk mengalami gangguan mental emosional, sedangkan yang tamat SLTP/sederajat mempunyai risiko 1,45 kali lebih besar. Responden yang tamat SD/sederajat mempunyai risiko 1,7 kali lebih besar dan yang tidak tamat SD atau tidak sekolah mempunyai risiko 1,9 kali lebih besar untuk mengalami gangguan mental emosional. Tingkat pendidikan seorang usia lanjut berbanding positif langsung dengan tingkat kesehatan jiwanya. ${ }^{20}$
Pendidikan rendah berhubungan dengan meningkatnya risiko untuk dimensia dan sebagian depresi. Hal ini mungkin bagi mereka yang berpendidikan rendah mempunyai keterbatasan dalam pola koping terhadap permasalahan-permasalahan yang dialami. Namun, mereka yang berpendidikan lebih tinggi memiliki kemampuan dan pengetahuan yang lebih sehingga berdampak terhadap kemampuan mengatasi persoalan hidup dan cenderung mampu mengatasi permasalahan. Untuk itu, risiko mengalami gangguan mental emosional lebih rendah. ${ }^{21}$

Faktor keturunan merupakan risiko terbesar untuk mengalami gangguan mental emosional. Responden yang mempunyai riwayat keluarga dengan gangguan jiwa, mempunyai risiko 3,8 kali lebih besar untuk mengalami gangguan mental emosional dibandingkan responden yang tidak mempunyai riwayat keluarga dengan gangguan mental. Individu atau responden yang mengalami gangguan jiwa/mental mempunyai masalah dengan kemampuan kognitif, afektif, dan psikomotor serta hubungan sosial. Walaupun prognosis terakhir dikatakan sembuh, pada dasarnya individu tersebut masih mempunyai gejala sisa. Jadi, pascasakit/gangguan yang pertama faktor genetik tetap mempunyai peran dalam kemungkinan terjadinya gangguan jiwa berikutnya (kambuh).

Faktor keturunan yang memengaruhi kesehatan jiwa seseorang, pada kasus tertentu seperti retardasi mental, terdapat kromosom trisomi pada pasangan kromosom nomor 21. Berdasarkan teori neurologi serta adanya faktor konstitusi yang menunjukkan genetik keseluruhan ataupun yang diperolehnya kemudian dari hasil interaksi genotip dan fenotip tersebut. Ditambahkan bahwa risiko terjadinya gangguan jiwa depresi pada saudara kembar lebih tinggi lagi yang faktor genetiknya berperan dalam terjadinya gangguan jiwa depresi pada saudara kembar monozigot sebesar $60-80 \%$, sedangkan pada saudara kembar heterozigot sebesar $25-35 \%$.

Jika tidak mendapatkan penanganan yang baik, hubungan antara depresi atau gangguan mental emosional dengan penyakit kronis dapat menjadi semakin buruk. Adanya efek dari gangguan mental makin memperparah penyakit kronis. Efek dari penyakit kronis juga makin memperparah gangguan mental emosional serta memperburuk kondisi disabilitas. Hubungan yang kompleks ini harus mendapatkan prioritas penanganan dengan memperbaiki sistem pengobatan penyakit kronis bersamaan dengan perbaikan penanganan gangguan mental emosional. ${ }^{22}$

Instrumen Hospital Anxiety and Depression Scale (HADS) tersedia dan direkomendasikan sebagai alat ukur yang cukup mudah dan efisien dalam mendeteksi gangguan mental pada pasien dengan penyakit kronis seperti kanker, jantung, pembuluh darah, dan pasien dengan penyakit muskuloskeletal. Petugas kesehatan sebaiknya dilatih dan dimotivasi untuk mendeteksi gang- 
guan mental emosional pada pasien penyakit kronis sejak awal sebelum pengobatan dimulai. Keuntungan mengetahui lebih awal kondisi gangguan mental emosional adalah pasien dapat diberikan penanganan tambahan berupa intervensi psikologi oleh spesialis kesehatan mental. Dengan demikian, pengobatan bisa dilakukan dengan lebih efektif, kesembuhan pasien bisa lebih cepat, juga menurunkan biaya pelayanan kesehatan. ${ }^{23}$

Penelitian potong lintang ini mempunyai keterbatasan, yakni tidak dapat memastikan urutan waktu kejadian dan tidak dapat memastikan bahwa gangguan mental emosional terjadi belakangan. Pengukuran yang dilakukan pada saat yang bersamaan menyebabkan gangguan mental emosional dan variabel prediktornya dapat saling mendahului, akibatnya aspek kausalitasnya menjadi kurang jelas. Namun demikian, hasil penelitian ini sejalan dengan penelitian terdahulu yang rancangannya prospektif, maka dapat dipastikan bahwa hasil penelitian ini cukup akurat dan dapat dipercaya.

\section{Kesimpulan}

Satu dari sepuluh orang penduduk Indonesia usia 15 tahun atau lebih mengalami gangguan mental emosional. Sekitar 3,5\% penduduk Indonesia usia 15 tahun atau lebih mengalami salah satu dari enam penyakit kronis berikut yaitu TBC, diabetes mellitus, tumor atau keganasan, stroke, hepatitis atau lever, dan jantung. Dari sepuluh penderita penyakit kronis, dua sampai lima penderita akan mengalami gangguan mental emosional. Risiko gangguan mental emosional semakin tinggi bersamaan dengan semakin banyak jumlah penyakit kronis yang diderita oleh responden. Responden yang menderita satu penyakit kronis berisiko 2,6 kali lebih besar untuk mengalami gangguan mental emosional, yang menderita dua penyakit kronis berisiko 4,6 kali, yang menderita tiga penyakit kronis atau lebih berisiko 11 kali. Risiko gangguan mental emosional lebih besar pada mereka yang mempunyai riwayat keluarga dengan gangguan jiwa, jenis kelamin perempuan, perokok dan peminum alkohol, pendidikan rendah, tidak bekerja, janda/duda yang cerai mati atau cerai hidup, dan kelompok usia tua atau diatas 55 tahun.

\section{Saran}

Kementerian Kesehatan, Direktorat Bina Pelayanan Kesehatan Jiwa disarankan agar membuat kebijakan program pembinaan pelayanan kesehatan jiwa terkait dengan upaya promotif maupun preventif dalam pencegahan terjadinya gangguan mental emosional di Indonesia. Kebijakan ini dapat dilakukan dengan pembuatan pedoman atau standar pelayanan tentang penyakit kronis yang terkait dengan penurunan risiko gangguan mental emosional serta dibentuknya tim bimbingan teknis pelayanan tersebut di semua pe- merintah daerah, dinas kesehatan, dan rumah sakit. Praktisi kesehatan juga diharapkan dapat memperhatikan aspek mental emosional dalam pemberian pelayanan kesehatan (terutama pada pasien penderita penyakit kronis). Namun, bila ditemukan gangguan mental yang lebih berat, dapat disarankan segera merujuk kepada ahli yang lebih kompeten.

\section{Daftar Pustaka}

1. Maslim R. Buku saku diagnosis gangguan jiwa: rujukan ringkas dari PPDGJ. 3rd ed. Jakarta: Buku Kedokteran EGC; 2003.

2. Koenig HG, Vandermeer J, Chambers A, Burr-Crutchfield L, Johnson J. Minor depression physical outcome trajectories in heart failure and pulmonary disease. Journal of Nervous and Mental Disease. 2006; 194(3): 209-17.

3. Davies T, Craig TK. ABC kesehatan mental. Alifa Dimanti, penerjemah. Jakarta: Buku Kedokteran EGC; 2009.

4. WHO. Prevent chronic disease: a important investment. WHO: Geneva; 2006 [cited 2012 Desember 7]. Available from: http://www.who. int/chp/chronic_disease_report.

5. WHO World Mental Health Survey Consortium. Prevalence, severity, and unmet need for treatment of mental disorders in the WHO world mental health surveys. JAMA [serial on the internet]. 2004; 291 (21): 2581-90 [cited 2012 Dec 7]. Available from: http://jama.amaassn.org/cgi/content/full/291/21/2581.

6. Departemen Kesehatan. Laporan hasil riset kesehatan dasar: Riskesdas Indonesia tahun 2007). Jakarta: Departemen Kesehatan Republik Indonesia; 2008.

7. Miller TQ, Smith TW, Turner CW, Guijarro ML, Hallt AJ. A meta-analytic review of research on hostility and physical health. Psychological Bulletin. 1996; 119(2): 322-48.

8. Dwight MM, Kowdley KV, Russo JE, Ciechanowski PS, Larson AM, Katon WJ. Depression, fatigue and functional disability in patients with chronic hepatitis C. Journal of Psychosomatic Research. 2000; 49: 311-7.

9. Yayasan Stroke Indonesia. Seri gaya hidup sehat: cara bijak hadapi stroke, jantung \& pembuluh darah. Jakarta: PT Gramedia; 2007.

10. Kleinbaum DG. Logistic regression: a self learning text. $2^{\text {nd }}$ ed. New York: Springer-Verlak Inc; 2010.

11. Baumeister H, Härter M. Prevalence of mental disorders based on general population. Surveys. Social Psychiatry and Psychiatric Epidemiology. 2007; (42): 537-46.

12. Kessler RC, Demler O, Frank RG, Olfson M, Pincus HA, Walters EE, et al. Prevalence and treatment of mental disorders, 1990 to 2003. The New England Journal of Medicine. 2005; 352: 2515-23.

13. Serrano-Blanco A, Palao DJ, Luciano JV, Pinto-Meza A, Luja L, Fernandez A, et al. Prevalence of mental disorders in primary care: results from the diagnosis and treatment of mental disorders in primary care study (DASMAP). Social Psychiatry and Psychiatric Epidemiology. 2010; 45: 201-10.

14. Hawari D. Manajemen stres, cemas dan depresi. 1st ed. Jakarta: Fakultas Kedokteran UI; 2008.

15. Maramis WF, Maramis AA. Ilmu kedokteran jiwa. $2^{\text {nd }}$ ed. Surabaya: Airlangga Press; 2009.

16. Page A, Taylor R, Hall W, Carter G. Mental disorders and socioeconomic 
status: impact on population risk of attempted suicide in Australia. Suicede and Life-Threatening Behaviour. 2009; 39(5): 471-81.

17. Vos T, Mathers C, Herrman H, Harvey C, Gureje O, Bui D, et al. The burden of mental disorders in Victoria, 1996. Social Psychiatry and Psychiatric Epidemiology. 2001; (36): 53-62.

18. Roosihermati B. Penyakit kronis dan gangguan emosional di Indonesia. Jakarta: Puslitbang Sistem dan Kebijakan Kesehatan Depkes RI; 2008.

19. Stuart G. Keperawatan jiwa. In: Ramona KA, Egi K, penerjemah. Jakarta: Buku Kedokteran EGC; 2007.

20. Darmojo RB. Gerontologi sosial: masalah sosial dan psikologik golongan lanjut usia. Dalam: Darmojo RB, Martono HH, editor. Geriatri: ilmu kesehatan usia lanjut. 3rd ed. Jakarta: Balai Penerbit FKUI; 2004.

21. Gallo JJ. Epidemiology of mental disorder in middle age and late life. Epidemiology Review. 1995; 17 (1): 83-90.

22. Chapman DP, Perry GS, Strine TW. The vital link between chronic disease and depressive disorders. Prev Chronic Dis [serial on the internet] 2005 Jan [cited 2012 Dec 7]. Available from: URL: http://www.cdc.gov/pcd/issues/2005/jan/04_0066.htm.

23. Härter M, Woll S, Wunsch A, Bengel J, Reuter K. Screening for mental disorders in cancer, cardiovascular and musculoskeletal diseases: comparison of HADS and GHQ-12. Social Psychiatry and Psychiatric Epidemiology. 2006; 41: 56-62. 